\title{
BRPKM
}

Buletin Riset Psikologi dan Kesehatan Mental

http://e-journal.unair.ac.id/index.php/BRPKM

e-ISSN: 2776-1851

ARTIKEL PENELITIAN

\section{Pengaruh Strategi Koping terhadap Stres Akademik Siswa SMA pada Masa Pandemi Covid-19}

\author{
RIZKY EL HAKIM \& IKE HERDIANA* \\ Fakultas Psikologi Universitas Airlangga
}

\begin{abstract}
ABSTRAK
Penelitian ini bertujuan untuk mengetahui pengaruh antara strategi koping terhadap stres akademik dalam masa pandemi Covid-19. Strategi koping diukur dengan BRIEF Cope dan stres akademik diukur dengan ESSA. Partisipan dalam penelitian ini adalah siswa SMA dengan rentang usia 15-18 tahun. Metode pengambilan data menggunakan metode kuantitatif dengan menggunakan survei berupa google form. Uji reliabilitas alat ukur BRIEF Cope sebesar 0.809 dan alat ukur ESSA sebesar 0.804. Analisis data menggunakan regresi linear sederhana menggunakan SPSS 25 for windows. Hasil pada penelitian ini ditemukan signifikansi sebesar 0.0000 di mana kurang dari $0.05(\mathrm{p}=0.000<0.05)$. Dari data tersebut dapat disimpulkan bahwa strategi koping berpengaruh secara signifikan terhadap stres akademik dalam masa pandemi Covid-19.
\end{abstract}

Kata kunci: pandemi, strategi koping, stres akademik

\begin{abstract}
This study aims to determine the effect of coping strategies on academic stress during the Covid-19 pandemic. Coping strategies are measured with BRIEF Cope and academic stress is measured with ESSA. The participants in this study were high school students with an age range of 15-18 years. The method of collecting data is quantitative using a survey in the form of a google form. The reliability test of the BRIEF Cope measuring instrument is 0.809 and the ESSA measuring instrument is 0.804. Data analysis using simple linear regression using SPSS 25 for windows. The results in this study found a significance of 0.0000 which is less than $0.05(\mathrm{p}=0.000<0.05)$. From this data, it can be concluded that coping strategies have a significant effect on academic stress during the COVID-19 pandemic.
\end{abstract}

Keywords: academic, coping strategy, stress pandemic

Buletin Penelitian Psikologi dan Kesehatan Mental (BRPKM), 2021, Vol. 1(1), 976-984

*Alamat korespondensi: Fakultas Psikologi Universitas Airlangga, Kampus B Universitas Airlangga Jalan

Airlangga 4-6 Surabaya 60286. Surel: ike.herdiana@psikologi.unair.ac.id

Naskah ini merupakan naskah dengan akses terbuka dibawah ketentuan the Creative Common Attribution License (CC-BY-4.0) (http://creativecommons.org/licenses/by/4.0), sehingga penggunaan, distribusi, reproduksi dalam media apapun atas artikel ini tidak dibatasi, selama sumber aslinya disitir dengan baik. 


\section{PEN D A H U L U A N}

Masa remaja merupakan masa transisi dari anak-anak menuju dewasa. Remaja sendiri berasal dari kata adolescene di mana memiliki arti to grow atau to grow maturity. Remaja memiliki ciri di mana mereka mulai berpendapat, mudah dipengaruhi oleh teman, mengalami perubahan fisik yang mencolok dan memiliki rasa percaya diri yang tinggi (Putro, 2017). Selain memiliki perubahan fisik, remaja juga mengalami perubahan psikologis. Menurut Jahja (2011) remaja mengalami peningkatan emosional yang cepat yang dikenal sebagai masa storm and stress. Peningkatan emosional tersebut merupakan akibat dari perubahan fisik pada remaja.

Pada fase ini remaja mengalami banyak tekanan dan tuntutan sosial, seperti sikap, kemandirian, dan tanggung jawab (Putro, 2017). Batasan usia remaja dibagi menjadi tiga bagian, yaitu usia 12-15 tahun pada awal remaja, usia 15-18 tahun pada pertengahan masa remaja dan usia 18-21 tahun pada akhir pubertas (remaja akhir) (Sarwono, 2004). Remaja memiliki tugas untuk menerima perubahan fisiknya, memiliki kemandirian emosional, mengembangkan keterampilan komunikasi, dan memperkuat pengendalian diri. Dari penjelasan di atas, remaja dengan usia 15-18 merupakan remaja yang berada pada jenjang sekolah menengah. Tugas siswa dalam masa remaja, yaitu untuk terus belajar dan mengembangkan dirinya di lingkungan sosial untuk mempersiapkan masa depan (Putro, 2017).

Pada awal tahun 2020, muncul suatu virus yang menyebabkan pandemi. Virus ini menimbulkan berbagai masalah di setiap negara. Mulai dari kekacauan ekonomi, sosial, politik bahkan pendidikan. Dalam pendidikan sendiri, pemerintah mengambil langkah dengan merubah sistem pembelajaran tatap muka menjadi daring. Hal tersebut ditetapkan oleh Kementerian Pendidikan dan Kebudayaan (Kemendikbud) yang menerbitkan Surat Edaran Nomor 15 Tahun 2020 tentang "Pedoman Penyelenggaraan Belajar dari Rumah Dalam Masa Darurat Penyebaran Covid-19”. Surat Edaran Nomor 15 ini untuk memperkuat Surat Edaran Mendikbud Nomor 4 Tahun 2020 tentang Pelaksanaan Pendidikan Dalam Masa Darurat Coronavirus Disease (Covid-19). Dalam surat edaran ini disebutkan bahwa tujuan dari pelaksanaan pembelajaran daring adalah memastikan pemenuhan hak peserta didik untuk mendapatkan layanan pendidikan selama darurat Covid-19, melindungi warga satuan pendidikan dari dampak buruk Covid-19, mencegah penyebaran dan penularan Covid-19 di satuan pendidikan dan memastikan pemenuhan dukungan psikososial bagi pendidik, peserta didik, dan orang tua (Kemendikbud RI, 2020).

Adanya kebijakan tersebut tentunya menimbulkan berbagai macam hal terhadap dunia pendidikan. Hal tersebut terjadi dikarenakan perubahan yang mendadak dan ketidaksiapan baik tenaga pengajar maupun siswa. Salah satu hal yang ditimbulkan yaitu adanya goncangan pada psikologis siswa. Berdasarkan hasil survei yang dilakukan Litbang Kompas, sebanyak 28,3\% siswa mengalami stres jika sistem ini berlangsung lama (Mediana, 2020). Kemudian, Komisi Perlindungan Anak Indonesia (KPAI) menerima laporan bahwa 79,9\% siswa tidak senang belajar dari rumah karena 76,8\% guru tidak melakukan interaksi selain memberikan tugas (Fakhri, 2020). Komisi Perlindungan Anak Indonesia (KPAI) melakukan survei lain terkait pembelajaran daring yang sudah berlangsung selama empat minggu. Hasilnya, tercatat ada 246 aduan dari siswa, paling banyak yaitu tentang keluhan tugas yang menumpuk dengan waktu pengumpulan yang singkat. Survei itu dilakukan pada tanggal 13 April-20 April 2020 dengan total responden 1.700 gabungan siswa dari jenjang TK sampai SMA/sederajat. Dari 1.700 responden, sebanyak 77,8\% siswa kesulitan karena tugas yang menumpuk antarguru. Terlebih, waktu pengumpulan tugas yang terbilang pendek. Selain itu, interaksi siswa dan guru dalam pembelajaran daring selama masa belajar di rumah akibat pandemi Covid-19 sangat minim. Dalam survei yang dilakukan ditemukan tingkat interaksi hanya 20\%. Adapun interaksi yang dilakukan hanya sebatas memberi dan menagih tugas yang diberikan guru. Sebanyak 79,9\% responden menyatakan, interaksi belajar mengajar seperti pada ruang kelas sudah hilang (Tim KPAI, 2020). 


\section{Pembelajaran Daring}

Menurut Bonk (2002) secara tersirat mengemukakan dalam survei Online Training in an Online World bahwa konsep pembelajaran daring sama artinya dengan e-learning. Pembelajaran daring didefinisikan sebagai "instructional content or learning experiences delivered or enabled by electronic technology" (Riyana, 2019). Pembelajaran daring membutuhkan beberapa persyaratan untuk siswa, yaitu ICT literacy di mana siswa mampu menguasai teknologi informasi dan komunikasi yang merupakan dasar untuk belajar daring, kemudian Independency di mana dalam pembelajaran daring membutuhkan siswa yang telah terbiasa belajar mandiri, yaitu memanfaatkan fasilitas belajar daring tanpa harus dibimbing langsung oleh guru, dan Creativity and Critical Thinking di mana fasilitas pembelajaran daring sangat beragam, siswa dapat mempelajari berbagai tools atau media yang tersedia. Hal ini menuntut adanya kreativitas siswa untuk memanfaatkan semua dengan optimal (Riyana, 2019).

\section{Stres Akademik}

Stres akademik adalah tekanan mental yang berhubungan dengan rasa frustasi yang berkaitan dengan kegagalan akademik atau kesadaran mengenai kemungkinan kegagalan yang akan terjadi. Stres akademik mengacu pada kondisi psikologis yang tidak menyenangkan yang disebabkan oleh harapan pendidikan orang tua, guru, teman sebaya dan anggota keluarga, terutama tekanan orang tua terhadap prestasi akademik (Sarita \& Sonia, 2015). Selain itu tekanan akademik disebabkan oleh rasa frustasi yang berkaitan dengan kegagalan akademik, bahkan tekanan mental yang disebabkan oleh ketidaksadaran akan kemungkinan kegagalan. Siswa harus menghadapi banyak persyaratan di luar kemampuannya dan pada akhirnya mengalami tekanan karena persyaratan untuk mencapai tujuan akademis (Lal, 2014).

\section{Strategi Koping}

Strategi koping merupakan strategi yang digunakan untuk mengatasi stres yang sangat mempengaruhi kemampuan beradaptasi individu (Lazarus, 2006). Strategi koping adalah suatu pilihan strategi atau metode berupa respon tingkah laku atau pemikiran dan sikap, digunakan untuk memecahkan masalah yang ada dan beradaptasi dengan lingkungan yang penuh tekanan. Pada dasarnya strategi koping menggambarkan proses aktivitas kognitif, yang disertai dengan aktivitas perilaku (Indirawati, 2006). Strategi koping dalam penelitian ini adalah strategi koping individu ketika menghadapi situasi sulit, menghadapi pembelajaran daring yang penuh tekanan dan beradaptasi dalam kondisi dan situasi yang sulit pada masa pandemi.

Beberapa penelitian telah dilakukan terkait strategi koping dan stres akademik dalam masa pandemi. Pada penelitian yang dilakukan oleh Herna \& Evelyn (2021) menunjukkan pembelajaran daring saat pandemi menyebabkan menyebabkan stres. Hal tersebut disebabkan kebingungan, menjadi pasif, kurang kreatif dan produktif, penumpukan informasi yang kurang bermanfaat pada saat pembelajaran daring. Dalam mengurangi stres yang dialami, subjek menggunakan beberapa strategi koping yang dapat dilakukan yaitu berupa problem focused coping dan emotion focused coping (Angelica \& Tambunan, 2021).

Dalam penelitian yang dilakukan oleh Della \& Alviyatun (2020) menemukan penyebab stres akademik adalah banyaknya tugas yang menumpuk, bosan, dan tidak adanya bantuan yang diberikan oleh orang sekitar. Selain itu minimnya interaksi yang membuat materi sulit dimengerti. Dalam mengatasi hal tersebut, strategi koping yang digunakan adalah dengan mengatur jadwal agar terorganisir, kemudian mencari dukungan sosial berupa bantuan orang lain, selain itu selalu berpikiran positif dan mengambil hikmah yang terjadi saat ini (Tri Damayamti \& Masitoh, 2020). 
Berdasarkan tinjauan literatur yang telah didapatkan, peneliti menemukan bahwa kasus siswa mengalami stres akademik di Indonesia masih cukup tinggi, ditambah dengan adanya pandemi membuat siswa perlu melakukan adaptasi selama proses pembelajaran. Selain itu dari tinjauan literatur tersebut, peneliti menemukan bahwa stratgi koping berperan penting terhadap stres akademik. Kemudian, ditemukan pula dalam penelitian terdahulu bahwa salah satu faktor yang memengaruhi stres akademik adalah adanya kemampuan strategi koping. Dari penjelasan tersebut, peneliti memutuskan untuk melakukan penelitian untuk menemukan apakah terdapat pengaruh strategi koping terhadap stres akademik dalam masa pandemi Covid-19 pada siswa SMA. Sementara tujuan dari penelitian ini adalah untuk mengetahui pengaruh strategi koping terhadap stres akademik dalam masa pandemi Covid-19 pada siswa SMA. Hipotesis pada penelitian ini adalah terdapat pengaruh signifikan antara strategi koping terhadap stres akademik dalam masa pandemi pada siswa dan tidak terdapat pengaruh signifikan antara strategi koping terhadap stres akademik dalam masa pandemi pada siswa.

\section{Desain Penelitian}

\section{MET ODE}

Penelitian ini menggunakan metode kuantitatif, yang menggunakan beberapa variabel untuk diteliti dan menemukan hubungan antar variabel (Djamba \& Neuman, 2014). Penelitian kuantitatif yang digunakan dalam penelitian ini adalah penelitian kuantitatif eksplanatori. Neuman (2014) menjelaskan bahwa penelitian eksplanatori adalah penelitian yang didasarkan pada penelitian eksploratif dan deskriptif yang mengidentifikasi berbagai sumber perilaku sosial, kepercayaan, kondisi, dan berbagai peristiwa, mendokumentasikan penyebab dan kemudian menyediakan alasannya. Tujuan utama penelitian eksplanatori adalah untuk menjelaskan mengapa peristiwa tertentu terjadi dan untuk membangun, menguraikan, memperluas, atau menguji teori (Djamba \& Neuman, 2014). Penelitian ini menggunakan pendekatan kuantitatif eksplanatori karena berupaya membuktikan hipotesis penelitian yang akan dijelaskan kemudian.

Teknik pengumpulan data yang digunakan dalam penelitian ini adalah penelitian jenis survei. Alasan digunakannya survei ini adalah untuk mengumpulkan data dari sampel penelitian dengan menyebarkan skala psikologis dalam bentuk kuesioner. Kuesioner sendiri merupakan alat pengumpulan data penelitian yang sangat fleksibel dan relatif mudah digunakan dan data kuesioner dapat diklasifikasikan sebagai data faktual (Azwar, 2017).

\section{Partisipan}

Dalam menentukan partisipan pada penelitian ini, peneliti menggunakan teknik sampling non probability tipe purposive sampling. Purposive sampling dalam penelitian ini mempertimbangkan karakteristik yaitu siswa SMA yang berusia 15-18 tahun dan sedang menjalankan sistem pembelajaran daring yang diakibatkan oleh pandemi Covid-19. Teknik pengambilan responden menggunakan survey online dalam bentuk kuesioner google form.

Berdasarkan data yang telah didapatkan, jumlah responden dalam penelitian ini sebanyak 105 yang terdiri dari, perempuan dengan 89 responden atau 84.8\% dan laki-kaki sebanyak 16 respoden atau sebanyak 15.2\%. Rentang usia partisipan dalam penelitian ini terdiri dari 15 sampai dengan 18 tahun dengan usia terbanyak dalam penelitian ini adalah responden diusia 16 tahun dengan 53 respoden atau $50.5 \%$ dan responden paling sedikit ada direntang usia 18 tahun yang hanya ada 4 responden atau 3.8\%. Sedangkan pada usia 15 dan 17 tahun memiliki jumlah yang sama yaitu 24 responden atau 22.9\%. 


\section{Pengukuran}

\section{Skala Strategi Koping}

Untuk mengukur strategi koping peneliti menggunakan Brief COPE yang disusun oleh Carver (1997). Skala ini diadaptasi oleh peneliti dengan menerjemahkan skala ke dalam Bahasa Indonesia. Skala ini terdiri dari 28 item yang terdiri dari 14 dimensi yaitu active coping, planning, positive reframing, acceptance, humor, religion, using emotional support, using instrumental support, self-distraction, denial, venting, substance, behavioral disengagement, dan self-blame. Pada skala ini menggunakan butir skala Likert dengan rentang 1 hingga 4. Skor maksimal dari skala ini sebesar 112 dan skor minimal sebesar 28. Skala ini memiliki koefisien reliabilitas yang cukup baik $(\alpha=.809)$.

\section{Skala Stres Akademik}

Untuk mengukur stres akademik peneliti menggunakan Educational Stres Scale for Adolescents (ESSA) yang telah dikembangkan oleh Sun dkk., (2011). Skala ini diadaptasi dengan menerjemahkan skala ke dalam Bahasa Indonesia oleh penerjemah yang berpengalaman. Skala ini terdiri dari 16 aitem yang terbagi dalam 5 dimensi yaitu pressure from study, workload, worry about grades, self-expectation, dan despondency. Pada skala ini menggunakan butir skala Likert dengan rentang 1 hingga 4. Skor maksimal dari skala ini sebesar 64 dan skor minimal sebesar 16. Skala ini memiliki koefisien reliabilitas yang cukup baik $(\alpha=.804)$.

\section{Analisis Data}

Penulis menggunakan teknik analisa data regresi dengan bantuan apilakasi SPSS 25.0 for windows.

\section{HAS IL PEN ELIT IAN}

Hasil survei yang dilakukan oleh peneliti menemukan sebanyak 135 orang yang kemudian diseleksi kembali sehingga hanya 105 data yang diolah. Responden terdiri dari 89 responden perempuan atau 84.8\% dan laki-laki sebanyak 16 atau 15.2\%. Rentang usia dari 15 sampai dengan 18 tahun dengan usia terbanyak dalam penelitian ini adalah responden pada usia 16 sebanyak 53 atau $50.2 \%$ dan responden paling sedikit pada usia 18 sebanyak 4 atau 3.8\%.

Data deskriptif yang dilakukan oleh peneliti menemukan variabel strategi koping $(M=46.51, S D=8.586)$ sedangkan untuk variabel stres akademik $(M=47.07, S D=73.714)$.

Hasil uji regresi linier pada strategi koping dapat menjelaskan data $(F(1.103)=18.022 ; p<0.000$; $\mathrm{R}^{2}=0.149$ ) dan strategi koping mampu menjelaskan variasi stres akademik sebesar $14.9 \%$. Pada model tersebut nilai $\mathrm{p}$ yang diperoleh sebesar 0.000 yang menunjukkan adanya pengaruh signifikan strategi koping terhadap stres akademik.

\section{I S K U S I}

Berdasarkan uji asumsi normalitas pada penelitian ini menunjukkan bahwa distribusi data bersifat normal dan linier. Berdasarkan hasil analisis yang dilakukan didapatkan nilai koefisien korelasi sebesar - 0,247, hasil ini menunjukkan bahwa terdapat hubungan negatif yang signifikan antara strategi koping dengan stres akademik pada siswa. Hubungan negatif yang ditemukan dalam penelitian ini menjelaskan bahwa semakin tinggi strategi koping, maka stres akademik akan semakin rendah, dan begitu pula sebaliknya.

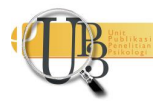


Berdasarkan analisis regresi kedua variabel menunjukkan adanya pengaruh strategi koping terhadap stres akademik, hal tersebut dilihat berdasarkan nilai taraf signifikansi, dalam penelitian ini ditemukan nilai taraf signifikansi sebesar 0.000, dan karena nilai tersebut lebih kecil dari 0.05, maka hipotesis alternatif $\left(\mathrm{H}_{\mathrm{a}}\right)$ dalam penelitian ini diterima dan hipotesis nol $\left(\mathrm{H}_{0}\right)$ ditolak. Strategi koping memiliki pengaruh sebesar $14.9 \%$ dan dengan arah pengaruh negatif terhadap stress akademik. Arah pengaruh yang negatif dapat diartikan yaitu semakin tinggi strategi koping yang dimiliki individu maka semakin rendah stres akademik. Sementara itu, sebesar $85.1 \%$ merupakan faktor lain yang memengaruhi stres akademik diluar strategi koping. Faktor lain yang sudah disebutkan yaitu kecemasan, partisipasi dalam pengambilan keputusan, dan kepuasan kerja (Ekawarna, 2018).

Terdapat dua tipe strategi koping menurut Lazarus (1984), yaitu problem focused coping dan emotion focused coping. Problem focused coping adalah upaya untuk melakukan suatu aktivitas untuk menghilangkan keadaan yang menimbulkan stres, sedangkan Emotion focused coping adalah di mana individu melakukan berbagai upaya yang bertujuan untuk mengubah fungsi emosional tanpa melakukan upaya langsung untuk mengubah stressor (Ekawarna, 2018). Kedua strategi koping tersebut dapat digunakan untuk mengatasi stres yang disebabkan pandemi Covid-19 di mana pada penelitian ini berfokus pada stres akademik.Strategi koping berperan secara efektif untuk mengatasi stres. Efektifitas tersebut juga bergantung pada strategi koping yang digunakan oleh individu tersebut. Beberapa faktor yang memengaruhi strategi koping meliputi kesehatan fisik, keyakinan atau pandangan positif, keterampilan memecahkan masalah, keterampilan sosial, dukungan sosial dan materi (Mu'tadin, 2002).

Penelitian yang dilakukan Syofian (2021) mengungkapkan bahwa pandemi Covid saat ini menyebabkan stres akademik. Stres akademik disebabkan oleh adanya pembelajaran daring, beban tugas yang berlebih dan waktu yang singkat pada pengumpulan tugas sehingga membuat siswa kewalahan. Dengan banyaknya tugas yang diterima, membuat siswa menghabiskan waktunya dari pagi hingga malam hanya untuk mengerjakan tugasnya. Untuk mengatasi permasalahan tersebut siswa menggunakan strategi koping jenis problem focused coping dimana siswa merencanakan semua kegiatan agar lebih terorganisir. Ada pula strategi koping berupa penerimaan dimana siswa mengambil hikmah dari keadaan yang ada. Koping tersebut merupakan koping yang berfokus pada emosi atau dikenal dengan emotion focused coping (Syofian, 2021).

Penelitian yang dilakukan oleh Herna \& Evelyn (2021) menemukan bahwa dalam menangani stress akademik dapat menggunakan kedua strategi koping, yaitu problem focused coping dan emotion focused coping. Strategi koping tersebut digunakan untuk mengatasi stres akademik akibat pembelajaran daring yang terjadi karena pandemi Covid-19. Dalam penelitiannya strategi koping yang digunakan adalah emotion focused coping. Strategi koping yang digunakan berupa pemecahan masalah, dukungan sosial, penilaian kembali secara positif dan kontrol diri (Angelica \& Tambunan, 2021).

Strategi koping merupakan Langkah yang tepat untuk digunakan Ketika mengalami stres dan ketika dihadapkan pada masalah yang sulit seperti penyesuaian diri yang mengharuskan individu mampu bertahan. Penyesuaian diri yang baik tentu didukung dengan strategi koping yang tepat. Dengan adanya strategi koping ini individu akan mampu beradaptasi dengan baik (Hidayah dkk., 2020).

Strategi koping yang baik diperlukan ketika mengalami stres. Stres akademik yang timbul akibat pandemic dapat dihadapi dengan menggunakan kedua strategi koping yaitu problem focused coping dan emotion focused coping. Kedua strategi koping ini berperan penting. Apabila individu hanya mengatasi stressor namun mengorbankan perasaannya maka tidak akan efektif. Begitu pula ketika individu hanya meredakan ketegangannya namun tidak menyelesaikan sumber masalahnya. Maka untuk mencapai strategi koping yang efektif diperlukan keduanya (Fitriasari dkk., 2020). 


\section{S I M P U L A N}

Berdasarkan hasil analisis data yang dilakukan peneliti mendapatkan bahwa terdapat pengaruh yang signifikan antara strategi koping dengan stres akademik, di mana pengaruhnya negatif yang berarti semakin tinggi strategi koping maka stres akademik semakin rendah.

Saran yang dapat diberikan peneliti adalah guru bisa memberikan edukasi terkait strategi koping bagi siswa agar mampu mengatasi stress akademik. Dengan adanya edukasi tersebut siswa akan mampu mengetahui strategi koping yang tepat untuk mengatasi stres akademik. Selain itu dukungan dari keluarga dan teman sebaya juga merupakan bentuk dari koping sehingga akan berdampak positif bagi individu Ketika mengalami stres. Bagi peneliti selanjutnya diharapkan untuk memperjelas atau mencari variable lain yang memengaruhi stress akademik, sehingga dapat diketahui apa saja faktor yang mempengaruhi stress akademik.

\section{U C A P A N T E R I MAKASIH}

Penulis berterima kasih kepada para partisipan yang sudah mengisi kuesioner pada penelitian ini dan membantu penulis dalam mengumpulkan data yang dibutuhkan. Penulis juga ingin mengucapkan terima kasih kepada semua pihak yang sudah membantu penulis untuk menyelesaikan penelitian yang tidak bisa penulis sebutkan satu per satu.

\section{DEKLARASI POTENSI TERJADINYAKONFLIK KEPENTINGAN}

Rizky El Hakim dan Ike Herdiana tidak bekerja, menjadi konsultan, memiliki saham, atau menerima dana dari perusahaan atau organisasi manapun yang mungkin akan mengambil untung dari diterbitkannya naskah ini.

\section{PUSTAKA ACUAN}

Angelica, H., \& Tambunan, E. H. (2021). Stres Dan Koping Mahasiswa Keperawatan Selama Pembelajaran Daring Di Masa Pandemik Covid-19. Jurnal Ilmiah Keperawatan Imelda, 7(1), 2834.

Azwar, S. (2017). Metode penelitian psikologi. Yogyakarta: Pustaka Pelajar.

Bonk, C. J. (2002). Online training in an online world. Bloomington, IN: CourseShare. com.

Carver, C. S. (1997). You want to measure coping but your protocol' too long: Consider the brief cope. International Journal of Behavioral Medicine, 4(1), 92-100. https://doi.org/10.1207/s15327558ijbm0401_6

Djamba, Y. K., \& Neuman, W. L. (2014). Social Research Methods: Qualitative and Quantitative Approaches. Teaching Sociology, 30(3), 380. https://doi.org/10.2307/3211488

Ekawarna. (2018). Manajemen Konflik dan Stres (1st ed.). Bumi Aksara.

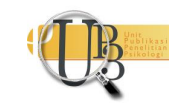


Fakhri, F. (2020, July 23). HAN 2020, KPAI Nilai Belajar Jarak Jauh Bikin Anak Tak Naik Kelas: Okezone Nasional. https://nasional.okezone.com/. https://nasional.okezone.com/read/2020/07/23/337/2250667/han-2020-kpai-nilai-belajarjarak-jauh-bikin-anak-tak-naik-kelas

Fitriasari, A., Septianingrum, Y., Budury, S., \& Khamida, K. (2020). Online Learning Stress Relates to Student Coping Strategies During the Covid-19 Pandemic. Jurnal Keperawatan, 12(4), 985-992.

Hidayah, N., Huriati, H., \& Sutria, E. (2021, March). TINGKAT STRES DAN STRATEGI KOPING MAHASISWA KEPERAWATAN DI MASA PANDEMI COVID19. In Seminar Nasional Variansi (Venue Artikulasi-Riset, Inovasi, Resonansi-Teori, dan Aplikasi Statistika) (Vol. 2020, pp. 184192).

Indirawati, E. (2006). Hubungan antara kematangan beragama dengan kecenderungan strategi coping. Jurnal Psikologi, 3(2), 69-92.

Jahja, Y. (2011). Psikologi Perkembangan. Kencana.

Kemendikbud RI. (2020, May 29). Kemendikbud Terbitkan Pedoman Penyelenggaraan Belajar dari Rumah. Kementerian Pendidikan, Kebudayaan, Riset, Dan Teknologi. https://www.kemdikbud.go.id/main/blog/2020/05/kemendikbud-terbitkan-pedomanpenyelenggaraan-belajar-dari-rumah

Lal, K. (2014). Academic stress among adolescent in relation to intelligence and demographic factors. American International Journal of Research in Humanities, Arts and Social Sciences, 5(1), 123 129.

Lazarus, R. S. (2006). Stress and emotion: A new synthesis. Springer Publishing Company.

Lazarus, R. S., \& Folkman, S. (1984). Stress, appraisal, and coping (11th ed.). Springer.

Masitoh, A. (2020). Strategi Koping Siswa dalam Menghadapi Stres Akademik di Era Pandemi Covid19. Academica: Journal of Multidisciplinary Studies, 4(2), 185-198.

Mediana. (2020, Juli 13). Siswa Alami Dampak Psikologis Pembelajaran Jarak Jauh Paling Nyata. Kompas.Id. https://www.kompas.id/baca/bebas-akses/2020/07/13/siswa-alami-dampakpsikologis-pembelajaran-jarak-jauh-paling-nyata

Mu'tadin, Z. (2002). Pengelolaan Stres. Wijaya Pustaka.

Putro, K. Z. (2017). Memahami ciri dan tugas perkembangan masa remaja. Aplikasia: Jurnal Aplikasi Ilmu-Ilmu Agama, 17(1).

Riyana, C. (2019). Produksi Bahan Pembelajaran Berbasis Online. Universitas Terbuka.

Sarita, S. (2015). Academic stress among students: Role and responsibilities of parents. International Journal of Applied Research, 1(10), 385-388.

Sarwono, S. W. (2004). Psikologi Remaja (2nd ed.). Raja Grafindo Persada. 
Sun, J., Dunne, M. P., Hou, X., \& Xu, A. (2011). Educational Stress Scale for Adolescents: Development, Validity, and Reliability With Chinese Students. Journal of Psychoeducational Assessment, 29(6), 534-546. https://doi.org/10.1177/0734282910394976

Syofian, E. F. (2021). Strategi Koping dalam Menangani Stres dari Pembelajaran Daring di Masa Pandemi COVID-19 [Preprint]. Open Science Framework. https://doi.org/10.31219/osf.io/2xkb6

Tim KPAI. (2020, April 28). Ada 246 Aduan di KPAI soal Belajar Daring, Siswa Keluhkan Tugas Menumpuk-Kuota. Komisi Perlindungan Anak Indonesia (KPAI). https://www.kpai.go.id/publikasi/ada-246-aduan-di-kpai-soal-belajar-daring-siswakeluhkan-tugas-menumpuk-kuota 